\title{
Türk Yazı Devrimi
}

\section{Turkish Alphabet Revolotion \\ Ali GÜRSEL*}

$\ddot{O} \mathbf{z}$

Tarihte büyük bir devlet kurmuş olan Türkler, İslamiyet'i kabul ettikten sonra Arap alfabesi Türklere yayılmış ve uygulanmıştır. $\mathrm{Bu}$ nedenlerden dolayı yazım kuralları sürekli değişmiş, ancak Türkçe'ye uygulaması başarılamamıştı. Özellikle Tanzimat'tan sonra basın ve yayın hayatının gelişmesine paralel olarak alfabe tartışmaları da başlamışıır. Bu tartışmalar Cumhuriyet devrinde de devam etmiştir. Okumayı ve yazmayı kolaylaştırmak, Türk milletinin eğitim ve kültür düzeyine yükseltmek ve ulusal kültürünü oluşturmak amacıyla çağdaş uygarlığa ulaşmak maksadıyla yapılan harf devrimi başarıya ulaşmış ve gerçekleşmiştir. Türk yazı devrimi büyük bir olaydır. Her büyük olay gibi bu konu da dil konusu, eğitim konusu ve kültür konusu olarak ele alınabilir.

Anahtar Kelimeler: Yazı, Devrim, Eğitim, Türk.

\section{Abstract}

The Turks, who founded many states throughout history, adopted the Arabic alphabet upon converting to Islam; therefore, writing systems were continuously changed, but the Arabic alphabet could not be fully adapted to Turkish. Especially after the Tanzimat reform era, discussions on the alphabet gained momentum in parallel with the development of the press and publishing industry. These discussions continued in the Republican times. The alphabet reform gained success and was realized in order to ease literacy, to increase the educational and cultural level of the Turkish nation, to form a national culture, and to reach the ideals of the modern civilization. The Turkish alphabet revolution is a great achievement. Like every great achievement, this issue can be analyzed in three respects, namely language, education and culture.

Keywords: Alphabet, Education, Revolution, Turkish.

\section{Giriş}

Türk dilinin yayılma alanı Batı ve Doğu Türkistan'ın dışına taşmıştır. Altaylara, Çungurya'ya, Moğolistan'a kadar uzanır. Orta Asya'nın doğu bölgelerindeki Türkler, Çin yönetiminde Çinlileştiler. Dokuz boydan oluşan Oğuzlar ise, batıya doğru bir yayılma gösterdiler. 10-11. yüzyıllarda Oğuzlar güneydoğuya, kuzeye, güneybatıya, batıya doğru daha geniş ölçüde yayıldılar. 10. yüzyılın ikinci yarısında Oğuzlar İslamlığı kabul ettiler. Bunların büyük bölümü İslamlığı kabul ettiler ve Türkmen adını aldılar. Oğuzların Kınık boyundan gelen Selçuklular, güneybatıya inerken, Karahanlılar da Çin Türkistan'ına girdiler ${ }^{1}$. Selçuklulardan sonra ise Oğuzların Kayı boyundan gelen Osmanlılar egemen devlet olarak ortaya çıtı.

Osmanlılar döneminde Türk dili Kuzey Afrika'ya, Balkanlara, Batı Avrupa'ya kadar yayıldı. 16. yüzyılda ise Türk dili Hindistan'a kadar genişledi. Oğuzların kuzeybatıya yayılmaları Volga nehri yakınlarında durakladı. 13. yüzyılda Altınordu Devleti'nin resmi dili Türkçe idi. Kıpçak Türkçesi de 14-15. yüzyıllarda, Kölemenler döneminde yaygın bir kullanım alanı buldu. Geniş bir yayılma alanı bulan Türk dili lehçeleri yayıldıktan sonra ilişki kurdukları dillerde sözcük alım-veriminde bulunmuşlardır. Moğolca'dan Türkçe'ye, Türkçe'den Moğolca'ya, Türkçe'den Mançurca'ya, Hunca'dan Macarca'ya Arapça'dan Macarca'ya, Peçeneklerden Osmanlıca'dan Macarca'ya gibi karşılıklı etkileşim olmuştur ${ }^{2}$.

Bugün Türkiye olası Türk dil ve lehçelerinin söz varlığı gitgide Rusça söz bireyleriyle yüklü bir duruma gelmekte, Türkiye Türkçesine de henüz ayıklanmamış Arapça, Farsça söz bireylerinden başka, batı dillerinden sözcük ve terimler girmektedir.

\footnotetext{
${ }^{*}$ Dr. Öğr. Üyesi, Kilis 7 Aralık Üniversitesi, Fen Edebiyat Fakültesi, Tarih Bölümü, agursel@kilis.edu.tr

${ }^{1}$ Cumhuriyet Dönemi Türkiye Ansiklopedisi, Cilt: 9-10, İstanbul, 1983, s. 2576-2577.

${ }^{2}$ Cumhuriyet Dönemi Türkiye Ansiklopedisi, s. 2577.
} 
Türkçe'nin tarihsel dönemleri; Türkçe'nin yazı dili olarak geçirdiği tarihsel gelişim 4 kategoride incelenebilir. Eski Türkçe, orta Türkçe, yeni Türkçe ve çağımız Türkçesi ${ }^{3}$.

Eski Türkçe; 6-10. Yüzyılda Orhun ve Yenisey yazıtları ile Uygurca metinlerde kullanılan dildir. Orta Türkçe, Kaşgarlı Mahmut'un Divan-1 Lügatü't-Türk'ü yazdığ1 dönemde kullanılmıştır. Bu dönemde yapıtlar Uygur alfabesiyle, daha sonra Arap alfabesi ile yazılmıştır (11-15. Yüzyıl). Büyük Selçuklu İmparatorluğu'nun yıkılmasından sonra Oğuz lehçesi birkaç alt birime ayrılmıştır: Anadolu Türkçesi, Azerice ve Türkmence, Yeni Türkçe(15-20. Yüzyıl). Yazı dili olma oluşumunda bulunulan Türk lehçelerinin bu yüzyıllardaki durumu ise klasik Çağatayca'nın yerini Özbekçe almıştır. Kölemen Kıpçakcası ile Oğuzlaşmıştır ${ }^{4}$.

Çağdaş Türkçe, 20. Yüzyıl Türklerin oturdukları bölgelerdeki günümüz Türkçesidir. Bunların en önemlisi Türkiye Türkçesidir. Eski dönemde Osmanlıcadan dallarının iki kolu daha vardı ki; birisi Gagavuzca diğeri Kırım Osmanlıcasıdır. Türkiye Türkçesini konuşanların sayısı altmış milyonu geçtiği sanılmaktadır.

\section{Eski Türklerde Yazı}

\section{Köktürk Yazısı}

Orta Asya'da yaşayan yerli halkın kullandığı, Türklerin en eski yazısı 7 . ve 8 . yüzyıllardan kalmadır. Bu yazıların en eski olanı 688 ve 692 seneleri aralığında yazıldığı varsayılan Gobi yöresindeki Çoyren yazıtıdır. Daha sonraları ise 732 ve 733 senelerinde Orhon yazıtları dikilmiştir ${ }^{5}$. VIII. yüzyıldan beri bilim adamlarının ilgisini çeken Köktürk yazıtları 1893 yılında Danimarkalı Vilhelm tarafından çözülmüştür. Bu yazının Arami kökenli olduğu ileri sürülmüştür ${ }^{6}$.

\section{Uygur Yazısl}

VIII. yüzyıldan sonra Köktürk yazısı bırakılmış, Köktürklerin doğudaki uygarlık mirasçıları Uygur Türkleri (945-970) Köktürk yazısını bırakıp Uygur yazısını almışlardır. Uygur yazısı, Sogud yazısının Türkçe'ye uydurulmaş bir biçimiydi. 18 harfli bir yazıdır. İki üç harfin birleştirilmesi, ya da alta üste noktalar konması ile 23 sesi karşılıyordu. Köktürk yazısından daha yetersiz bir yazıdır. Fakat bu yazı türü ile de gerek Budist, gerek Maniheist Uygurlardan kalmış çeviri ve özgün çeşitli yapıtlar bulunmaktadır ${ }^{7}$.

Türkler, Uygur yazı çeşidini kullanmakla beraber Tibet, Mani ve Hint menşeili Brahmi yazılarını da kullanmışlardır.

Dünya'da ilk yazıya geçen ve en çok alfabe kullanan milletlerden birisi Türklerdir. Türkleri, Arap alfabesine muhtaç gibi göstermek çok ciddi bir yanılgıdan ibarettir. Türkler şu alfabeleri ve yazıtları kullanmışlardır. Tamgalı Say yazıtları, Yenisey yazıtları, Sülyet yazıtları ve Açık Taş alfabesi, Eksik yazısı, Bengü Taş yazıtları, Göktürk Alfabesi, Uygur Alfabesidir. Türkler M.Ö. 5. Yüzyılların, M.S. 8. Yüzyıla kadar Runik alfabesi kullanmışlardır. Yani bu da tam 1300 yıla denk gelmektedir. Bu alfabenin değiştirilmesine ses çıkarmayanlar, 600 yıl kullanılan Arap alfabesinin değiştirilmesine kıyameti koparıyorlar. Bir gecede cahil kaldıklarını söylüyorlar.

\footnotetext{
${ }^{3}$ Cumhuriyet Dönemi Türkiye Ansiklopedisi, s. 2578.

${ }^{4}$ Cumhuriyet Dönemi Türkiye Ansiklopedisi, s. 2578.

${ }^{5}$ Bilal Niyazi Şimşir, Türk Yazı Devrimi, Ankara, 1992, s. 1.

${ }^{6}$ Şimşir, Türk Yazı Devrimi, s. 3.

${ }^{7}$ Mehmet Şakir Ülkütaşır, Atatürk ve Harf Devrimi, Ankara, 1973, s. 15.
} 


\section{İslamiyetin Yayılışı ve Türk Dili}

Türkler dokuncu yüzyıl ortalarına doğru Müslümanlığa ve bunun etkisi ile Arap yazısının etkisi altına girmişlerdir. Türk tarihinde yeni bir süreç başlamıştır. Müslümanlık Arap yarım adasında doğmuştur; bu dinin peygamberi Araptır, kitabı Arapça'dır ve bu yeni din Araplara yeni ufuklar açar ${ }^{8}$. Araplar bu yeni dinle VII. yüzyılda Arabistan'dan çıkarak fetihlere girişerek bir Arap emperyalizmi oluşturmuşlardır.

Araplar Müslümanlığı benimseyen kitlelerin Araplaştırılması yoluna gittiler ve burada kısmen başarı da sağlanmıştır. Araplar saldırılarını doğuya yönelterek İran'a karşı harekete geçerler, burada Eski İran dili ile Arapça çarpışır sonunda Arapça galip gelir. İran'ın eski Pehlevi yazısı da Arap yazısı ile değiştirilir. Emevilerden Abdülmelik, aldığı yerlere Arapça'yı devlet dili olarak benimsetir.

Emeviler döneminde Araplar, Türklerin hakim olduğu yerlere kadar uzanırlar. İran'dan sonra Türklerle yüz yüze gelen Araplar, İslamiyet öncesi her şeyi batıl sayan Müslüman Arapların saldırıları Türklere çok ağır geldi. Türk gençlerine karşı çok acımasız davrandılar. Kadınlar, çocuklar tutsak edilir. Türkler gönüllü gönülsüz Müslümanlığı kabul ederler. Oğuz topluluk başında gelen Selçuklularda İran'a gelip yerleşerek bir takım siyasal nedenlerle Türklerin Müslümanlığı sürer gider.

Türkler, Müslümanlığı benimsemekle Araplaşmazlar. Kendi dillerini bırakmaz onu yaşatırlar. Hatta 1072 'de Kaşgarlı Mahmut Divan-1 Lügati't Türk'ü yazarak Türkçe'nin Arapça'ya üstün olduğunu göstermiştir. Fakat tüm bunlara rağmen Türkler, Fars, Arap kültürünün etkisi altına girerek, Selçuklu ve Osmanlı dönemlerinde camide din dili, bilim dili olarak ta medresede taht kurar. Medreselerde öğretimin Arapça yapılışı Batıdaki Latince gibi, Arapça bütün Türk ülkelerine yayılır. Yedeğinde ise Farsça vardır. Arap yazısı bütün İslam dünyasının yazısı durumuna gelmiştir. Arap yazısı tüm Osmanlı ve Selçuklu illerinin ortak yazısı olmuştur.

Türklerin Arap yazısını benimsemeleri belirli tarihsel koşullar altında olmuştur. Din değiştirmenin bir sonucudur. Arap yazısı Kuran'ın yazısı olduğu dinin bir parçası gibi görüldüğü için alınmıştır. Arap dili Türk diline tepeden inme giydirilmiştir. $\mathrm{Bu}$ iki dil temelden birbiriyle uyumlu değilken, Arap harfleriyle Türk seslerini saptama olanağı yoktur. $\mathrm{Bu}$ yazıya geçmede çetin zorluklar hemen kendini göstermiştir. Bu süreç yaklaşık beş yüz yıl sürmüştür.

İslamlaşan Türk, oldukça zengin olan ve altı ünlü sesi karşılayan Köktürk yazısından sonra, ünlü harflerden hemen hemen yoksun olan bir alfabe ile karşılaşmıştı. İster istemez Arap yazısına uymak zorunda kalmıştır ${ }^{9}$. Cennette kullanılan dilin Arapça, Farsça olduğunu ileri sürüyorlardi ${ }^{10}$.

\section{Osmanlı Devleti'nde Dil Çalışmaları}

18. yüzyılın ikinci çeyreğinin başlarında (1727) matbaanın Osmanlı'da kurulması, Türkçenin öneminin artmasında ciddi bir rol oynamıştır. 18. yüzyılda ordu için teknik eleman sağlamak için sivil okullar açılmış ve Türkçe dersler bu okullarda verilmiştir. III. Selim ve II. Mahmut'un sultanlıklarında askeri okullarda türlü Avrupa dilleri öğretilirken Türkçe’ye de yer verilmiştir ${ }^{11}$.

\footnotetext{
${ }^{8}$ Şimşir, Türk Yazı Devrimi, s. 3.

${ }^{9}$ Şimşir, Türk Yazı Devrimi, s. 6.

${ }^{10}$ Cumhuriyet Dönemi Türkiye Ansiklopedisi, s. 2579.

${ }^{11}$ Neriman Tongul, “Türk Harf İnkılâbı”, Atatürk Yolu Dergisi, Sayı: ,33/34, Kasım 2004, s. 104-105.
} 
Arap harflerinin değiștirilmesi ile ilk önemli tartıșma 1860'lı yıllarda bașlamıștır. Tanzimat'la başlayan eğitim ve kültür hayatındaki gelişmeler bu dönemde yetişen genç ve aydın kuşak bilgi ve birikimlerini yaymak için ve basın-yayın hayatının ortaya çıkmasıyla okuma-yazma, eğitim, kültür gibi ciddi sorunlar gündemde yerini almıștır. Bu nedenle bu konu bakımından en ciddi araç olan alfabe ve dil aydınları tarafından tartışma konusu olmuştur. Arapçanın ve Farsça'nın etkisi o kadar artmıştır ki; Türk Ulusu yerine millet-i Osmaniye adını uyduran Tanzimatçılar Türkçe’ye de Osmanlıca adını vermişlerdir. Saray ve meclis divan yazısını desteklerken, Yeniçeri Ocağı'da Halk Edebiyatı geleneğini devam ettiriyordu. Divan edebiyatının dili ustalık göstermekten öte hiçbir işe yaramıyorken Öz Türkçe halkın konuştuğu dil olarak yaşamaktaydı.

Arap alfabesinin iyileştirilmesi anlamında ilk önemli çalışma Münif Paşa tarafından başlatılmıştır $^{12}$. Münif Paşa verdiği bir konferansta Arapça-Farsça terkiplerin çokluğunun hareke kullanılmadığı için bir kelimenin çeşitli şekillerde okunduğunu, okumayı yazmayı zorlaştırdığı, büyük harf bulunmaması hasebiyle için özel isimlerin diğer isimlerden ayırt edilmesinde zorluklar yaşandığını Avrupa yazın hayatında ise böyle zorlukların olmadığını 67 yaşlarındaki çocukların ise okuyup yazabildiklerini söylemektedir. Alfabenin basit bir şekilde okunabilmesi için harflere işaret konulmalı, harfler ayrık yazılması, yeni sesli harfler bulunmalıdır.

Aynı şekilde Azerbaycanlı şair Ahunzade Fethali de, Arap harflerinin zorluğunu, Arap harflerinin kullanılmasının dini açıdan herhangi bir mecburiyetin bulunmadığını yeni bir yazının alınabileceğini belirtmiştir ${ }^{13}$.

Yazıda bir değişikliğe gidilmesi için taraftarlar giderek çoğalmaktadırlar. Tevfik Fikret, Ali Suavi, Terakki gazetesi yazarı Hayrettin Bey, Şinasi Bey ve Ebuzziya.

II. Meşrutiyet döneminin başlaması ile alfabe tartışmaları yeniden başladı. Maarif Bakanlığı tarafindan komisyonlar oluşturuldu. Enver Paşa 1913 yılında Harbiye Bakanı olunca orduda uygulamaya koyduğu yazıda yeterince tutmadı ve uygulamadan kaldırıld ${ }^{14}$. Harflerin ayrık yazılması sebebiyle.

$\mathrm{Bu}$ dönemde latin harflerinin alınması konusunda hayli cesur girişimler de olmuştur. Hüseyin Cahit, Abdullah Cevdet, Celal Nuri İleri, Kılıçzade Hakkı latin harflerinin alınması konusunu işlemişlerdir. Ayrıca Arap harflerinin Allah tarafından gönderildiğini dolayısıyla kutsallığını da ileri sürüyorlardı. Geçmişle tüm bağlarımızın kopacağını söylüyorlard1 ${ }^{15}$. Netice olarakta Arap harflerinin ıslahı konusunda da fikir birliği sağlanamamıştır. Latin harflerinin yavaş yavaş alınması gündeme giriyordu. Bazı Osmanlı aydınları Arapça'nın resmi dil olarak kabul edilmesini de ileri sürüyorlard1. ${ }^{16}$

XVI. yüzyıldan itibaren Arapça ve Farsça'nın tahakkümü altında kalan yazı dili, Türkçe konuşma dilinden uzaklaşarak yabancılaşmıştır. Aydınlar, Arapça ve Farsça'yı kullanırken halk Türkçe'de ısrarcı olmuştur. İşte Osmanlı'daki bu halk aydın arasında meydana gelen kopukluğun giderilmesi için devlet adamları ve aydınlar büyük çabalar harcamışlardır. Atatürk, durup dururken Arapça, Farsça sözcükleri dilden ayıklayıp öz Türkçe sözcüklere yönelmemişti. Bunun bir tarihsel alt yapısı vardır ${ }^{17}$.

\footnotetext{
${ }^{12}$ Şimşir, Türk Yazı Devrimi, s. 5.

${ }^{13}$ Ülkütaşır, Atatürk ve Harf Devrimi, s. 6.

${ }^{14}$ Tongul, "Türk Harf İnk1lâbı", s. 107.

${ }^{15}$ Ülkütaşır, Atatürk ve Harf Devrimi, s. 28.

${ }^{16}$ Enver Ziya Karal, Türkiye Cumhuriyeti Tarihi, İstanbul, 1975, s. 178.

${ }^{17}$ Sinan Meydan, Cumhuriyet Tarihi Yalanlarl, İstanbul, 2020, s. 471.
} 
1876-1908 yılları arasında alfabe ve harf tartışmaları yeniden başladı. Siyasal koşulların elverişsizliği bu olayı olumsuz yönde etkilemişti. Bu dönemin sonuna doğru Arap harflerinin düzeltilmesi veya latin harflerinin alınması yolunda aydınlar iki gruba ayrılmışlardır. Enver Paşa'nın başlattığı dil hareketi de başarısızlıkla sonuçlanmıştı ${ }^{18}$.

Osmanlı'da bilim ve edebiyat dili Arapça ve Farsça idi. Türkçe ise yalnızca halk nezdinde yaşamını sürdürüyordu. Medreselerde Türkçe yasaktı. Osmanlı'da Türkçe'nin öğrenim dili olarak kullanılmaya başlanması Deniz Harp Okulunun kurulması ile başlamıştır. (1773)

1793 tarihinde III. Selim tarafından kurulan Kara Harp Okulunda da dersler Türkçe verilmeye başlanmıştır. Yine II. Mahmut döneminde açılan tıp okulunda da dersler Türkçe verilmeye başlanmıştır ${ }^{19}$. Eğer Latin harflerine geçilirse eski ile olan bağlarımızın bütünüyle kopacağı fikri çok yaygındı. Tam da bu esnada Musullu Or. Davut Bey, Mebusan meclisine latin harflerine geçiş için bir tasarı sunmuş ve Latin harflerinin kabulünü önermiştir ${ }^{20}$.

1789 Fransız ihtilali nedeniyle batıda başlayan ulusallık fikri Osmanlıda da milliyetçi fikir ve düşüncelerin oluşmasına kaynaklık etmiştir. 1876 Kanun-i Esasi'ye göre de devlet hizmetlileri resmi dil Türkçe'yi bilmeleri zorunluluğu getirilmiştir. Türkçe'yi güçlendirmek için ilk dernek 1908 'de Selanik'te kurulmuştur ${ }^{21}$. Çünkü bunlar ulusal bir edebiyat dili İstanbul Türkçesini temel alarak yazı dili ve konuşma dilini bir araya getirmek amacını güdüyordu. Şinasi, Ziya Paşa, Ali Suavi, Namık Kemal, Ahmet Refik Paşa ve Şemsettin Sami gibi aydınlar, dilin sadeleşmesini savunuyorlardı.

Arap harflerinin iyileştirilmesi ve Latin harflerinin kabul edilmesi gibi iki gruba ayrılan görüşlerden Latin harflerinin alınmasına karar verilmiştir. Latin harflerinin alınması kararı Cumhuriyet Dönemi'nde gelişecek alfabe konusunda önemli ölçüde oluşturmuş ve yararlı olmuştur.

Mili mücadelenin ilk yıllarında 7-8 Ağustos 1919'da Mustafa kemal Mazhar Müfit Kansu'ya Kurtuluş Savaşı zaferle sonuçlandıktan sonra ülkede yapılacak yeniliklerden söz ederken yazının değiştirileceğini Latin harflerine geçileceğini söylemiştir ${ }^{22}$.

Azerbaycan hükümetinin 22 Temmuz 1922'de Latin kökenli bir yazıyı kabul etmesi üzerine Ankara'da hareketlenmiş ve biraz beklemeden sonra Türkçe'yi Arapça kalıplardan kurtarmak gerektiğini söylemiştir ${ }^{23}$.

\section{Cumhuriyet Devri Dil Çalışmaları}

Yüzyıllarca öz yapımızla uyuşmayan Arap alfabesiyle kaleme alınan ve Arapça, Farsça kelimelerin tahakkümü sonrası öz benliğini kaybeden Türkçe'yi yeniden kurtarmak mecburiyeti ortaya çıkmıştır. Gerçekte bu durum bir tarihsel mecburiyetin sonucudur.

Olağanüstü zor koşullarda kazanılan Milli Mücadele sonrasında yeni koşullar devletin varlığını devam ettirebilmesi ve sonsuza kadar yaşaması için çağın gereklerine ayak uydurmak zorundaydı. Atatürk kurtuluşun tek çıkışı olarak bilimi, teknolojiyi, kültür ile yani hayata bakış biçimiyle batı uygarlığını her şeyiyle almaktı. Atatürk çağdaş batı uygarlığına

\footnotetext{
${ }^{18}$ Harf Devrimimim 50. Yılı Sempozyumu, Ankara, 1981, s. 55-60; Tongul, “Türk Harf İnkılâbı”, s. 107.

${ }^{19}$ Şerafettin Turan, Atatürk ve Ulusal Dil, Ankara, 1998, s. 11; Osman Ergin, Türkiye Maarif Tarihi, Cilt: 2, İstanbul, 1977, s. 293.

${ }^{20}$ Tongul, "Türk Harf İnkılâb1", s. 108.

${ }^{21}$ Meydan, Cumhuriyet Tarihi Yalanlarl, s. 473.

${ }^{22}$ Tongul, “Türk Harf İnkılâbı”, s. 109; Mazhar Müfit Kansu, Erzurum'dan Ölümüne Kadar Atatürkle Beraber, C.1, Ankara, 1988, s. 131.

${ }^{23}$ Tongul, “Türk Harf İnkılâbı", s. 110.
} 
doğru ilerlerken onun budanmış bir şekilde alınmasına karşı çıkmıștı ${ }^{24}$. Milli Mücadele'nin en karanlık ve zorlu günlerinden başlayarak devamlı surette medenileşmekten asrileşmekten söz ediyordu. Zaferden çok kısa bir süre sonra da dünyadan kayıtsız yaşayamayız. Çağını, modern ve çağdaş yaşamın bilim ve tekniğini almayı gerektiğini belirtmişti. Lozan Antlaşmasından hemen sonra da kazanılan başarının Türkiye'ye uygarlık yolunda önemli bir adım attığını gerekli olanın bu istikamet üzere aralıksız ilerlemek olduğunu belirtmişti. Atatürk böylece Türkiye Cumhuriyeti'nin bağımsızlığı, Türk halkının huzur ve güven içinde hayatını sürdürmesi sonsuza dek sağlanacakt ${ }^{25}$.

Atatürk çağdaşlaşma yönünde değişmeler meydana gelmesi yani yeni kültür unsurlarının alınması ve toplumsal olarak kabul edilmesi için dönemin yeterli olmayan geleneksel kültür unsurlarından vazgeçilmesi üzerinde durarak ciddi şekilde incelemiştir. Örneğin, ikili eğitim, Osmanlı yazısı, geleneksel kıyafetler, toplum hayatı, evlilik, dini kurallara dayalı her türlü siyasi ve hukuki davranışlardır ${ }^{26}$.

Atatürk ve arkadaşlarının temel hedefi tam bağımsı Türkiye'nin çağdaş batı ülkelerinin seviyesine erişmek ve onların da önüne geçmekti. Bununda temel öğesi eğitim ve kültür hayatındaki gelişmelerdi.

Halkı yeni düşüncelerle eğitmek ve öğrenim oluşumunu yükseltmek gerekir. Aydınlar halkını kendi seviyesine ulaştırmalıdır. Toplumun eğitimini yeni ve basit yollarla sağlamaktır ${ }^{27}$.

Atatürk güçlüklerle kurduğu ülkenin kalkınması için hemen taarruz konuşmalarında da eğitim ve öğretimin önemi belirterek, harf devriminin zorunluluğunu belirtmişti.

Dil devriminin zorunluluğunu şöyle belirtebiliriz: 1) Türkçeyi, Türkçe'nin yapısına uymayan Arap alfabesinden kurtarmaktır. Arap alfabesi Arapça'ya uygun fakat Türkçe'ye uygun değildi ${ }^{28}$. 2) Okuma yazma oranını arttırmak, çağdaş batı ülkeleri seviyesinin üstine çıkarmaktır. 3) Batıdan daha iyi yararlanmak, batıdan alınan harflerle birlikte ölçüler, takvim, sanat da alınmıştır. 4) Arap harflerinin yarattığı toplumsal sınıflaşmadan kurtarmaktır. 5) Devrimi yerleştirmek için bir süreliğine geçmişle bağlarını askıya almak. 6) Kutsal yazı anlayışına son vermek. 7) Dış Türklerle bağları devam ettirmek gibi nedenlere dayanmaktır ${ }^{29}$.

Atatürk 1928'de yazı devrimini 1932'de ise dil devrimini gerçekleştirmiştir. Yazı ve dil devrimi birbirini tamamlayan devrimlerdir. Türkçe'nin yapısına uymayan Arap harfleri yerine Latin harfleri benimsenmiştir. Türeme, derleme, tarama çalışmaları yapılmıştır.

Prof. Dr. Muharrem Ergin, Arap harflerinin Türkçe'nin yapısına hiç uygun olmadığını ileri sürmüştür. Arap alfabesinde sadece üç tane sesli harf bulunduğunu, Türkçe sondan eklemeli bir dil, Arapça ise çekimli bir dildir. Arapça'da sesli harflerin okunuşu kuralsızd. Arap harflerinin yazılması okumayı zorlaştırmaktadır ${ }^{30}$.

\footnotetext{
${ }^{24}$ Tongul, "Türk Harf İnkılâbı", s. 110.

${ }^{25}$ Tongul, "Türk Harf İnkılâbı", s. 110.

${ }^{26}$ Abdurrahman Çaycı, “Atatürk ve Kültür Alanında Çağdaşlaşma”, Atatürk Kültür ve Eğitim Semineri, Kayseri, 1982.

${ }^{27}$ Afet İnan,50. Yllında Türk Harf Devrimi (1028), Harf Devriminin 50. Y1lı, Ankara, 1969, s. 79; Tongul, "Türk Harf İnkılâbı", s. 111.

${ }^{28}$ Bernard Lewis, Modern Türkiye’nin Doğuşu, 5. Baskı, Ankara, 1993, s. 421.

${ }^{29}$ Muharrem Ergin, “Türklerde Yazı ve Alfabeler”, Türk Dünyası El Kitabl, Ankara, 1976, s. 340-376; Meydan, Cumhuriyet Tarihi Yalanları, s. 477.

${ }^{30}$ Meydan, Cumhuriyet Tarihi Yalanlarl, s. 478; Muharrem Ergin, “Türklerde Yazı ve Alfabeler”, s. 340-376.
} 
Alfabe değişikliğine gitmenin önemli nedenlerinden birisi de okuma-yazma erkeklerde yüzde 7 , kadınlarda ise yüzde 4 okuma yazma oranı olduğunu belirtmektedir ${ }^{31}$. Falih Rıfkı Atay'da yazı ve dil değişikliğini destekleyenlerdendir.

Gerçekten Latin harflerinin alınmasından sonra Türkiye'de okuma yazma oranı önemli derecede artmıştır. Yüzde 4-7'lerden, 1950'lere gelindiğinde yüzde 45-50'lere varılmıştır.

Atatürk devrimleri akıl ve bilimi rehber edinmiştir. Türkiye'nin çağdaşlaşması hedeflenmiştir. Türkiye'nin çağdaşlaşması demek çağdaş kültür medeniyetten faydalanmak demekti. Türkiye'nin yararlanmaya çalıştığı Avrupa devletleri kendi dillerini Latin alfabesi ile yaymaktadırlar. Türkiye'nin de çağdaş batı değerlerinden ticari ekonomik, kültürel, sosyal ve bilimsel açılardan batı değerlerinden yararlanması anlamına gelir ki, çok önemlidir. Harflerle beraber batının kullandığı rakamlar, ölçüler, takvim ve saat gibi ölçülerde alınmıştır ${ }^{32}$.

Arapça dil kullanımı toplumda ikilik yaratmıştır. Saray ve yakın çevresi bu dili kullanırken geniş halk kitlesi bu harflerle okumayı ve yazmayı bilmiyordu. Arapça bilenler sanki ayrıcalıklıymış gibi özellikle din adamları Arapça yazılmış bir metni "dinsel bir metin" gibi halka sunarak onları kandırabiliyorlardı. Arapça herhangi bir yazılı metin sanki dinsel bir metin gibi zannediliyordu. İşte Latin alfabesine geçilmesinde bu kutsal yazı anlayışına da son vermek vardı. Ayrıca Atatürk, dış Türklerle Orta Asyalı Türklerle de ilişski kurarak onları Rus dili baskısından korumak istemiştir ${ }^{33}$. Ulus devleti güçlendirmek Türkçe'nin çok eski ve muhteşem bir dil olduğunu kanıtlamaktır. Özetle, Atatürk Türkçe'nin güzelliğini ve zenginliğini meydana çıkarmak onun dünya dilleri arasındaki kıymetine yakışır seviyeye ulaştırabilmek için dilimizi bir bilim kolu olarak ele alınarak üzerinde kaynaklarına inmek araştırmalar yapmaktır ${ }^{34}$.

\section{Latin Alfabesinin Kökeni}

Atatürk'ün Latin alfabesini alma çabalarına karşı Latin alfabesi batuya özgü bir alfabedir. Türk kültürünü ve dilini bu alfabe ile ifade etmenin doğru olmadığı görüşler vardır. Ülkemizin eğitim sistemindeki yetersizliği, Atatürk'ün ölümünden sonra yazı devriminden tekrar geriye doğru bir dönüş için ileri sürülen teoriler genel kabul görmeye başlamıştır ${ }^{35}$. Bu güçlük teoriye üniversitelerde sahiplenmek istemişlerdir. Oysa üniversiteler genel kabul gören görüş ve önerileri olduğu gibi kabul etmek değil, araştırmak ve sorgulamaktır. Latin alfabesi bize çok yabancı bir alfabe değildir.

\section{Runik Yazıları}

İlkçağ Orta Asya toplulukları, Etrüskler, Macarlar ve Kuzey Avrupa ülkeleri (İsveç, Norveç, Finlandiya ve Almanya) gibi devletler bu runik yazısını kullanmışlardır. Bu yazı 24 harfden oluşmuştur. Çoğu kaya üzerine yazılmış olan runik yazıtları M.S. 2. Yüzyıldan 17. Yüzyıla kadar tarihlenmekte ve sayıları 5.000'i aşmaktadır. Bunların çoğu İsveç'te, 1.000 tanesi Norveç'te, 700 kadarı ise Danimarka'dadır. Runik yazıları, Etrüsk ve ÖnTürk metinleri gibi sağdan sola yazılmıştır. Runik alfabesi Futhark alfabesi olarak da bilinmektedir ${ }^{36}$. Kazım Mirşan, Orta Asya Runik yazıtlarının, Batı Avrupa'dan daha eski olduğunu ileri sürerek batıya giden Orta Asyalı göçmenlerin bunu Avrupa'ya taşıdığını ileri sürmüştür. Rus, Aristov

\footnotetext{
${ }^{31}$ Sina Akşin, Ana Çizgileriyle Türkiye 'nin Yakın Tarihi, Cilt: 2, İstanbul, 1997, s. 68.

${ }^{32}$ Meydan, Cumhuriyet Tarihi Yalanlarl, s. 480.

${ }^{33}$ Meydan, Cumhuriyet Tarihi Yalanlarl, s. 481.

${ }^{34}$ Zeynep Korkmaz, "Atatürk ve Türk Dili”, Türk Dil Dergisi, Sayı: 655, 2006, s. 19; Meydan, Cumhuriyet Tarihi Yalanlarl, s. 484.

${ }^{35}$ Meydan, Cumhuriyet Tarihi Yalanları, s. 451; İsmail Doğan, Etrüsk Yazısının Kaynă̆ Türk (Göktürk) Tarihten Bir Kent, Ankara, 2008, s. 164.

${ }^{36}$ Meydan, Cumhuriyet Tarihi Yalanlarl, s. 452-453.
} 
gibi bilginlerce Türk Runik yazısı bu eski Türk yazılarından türetilmiştir. Runik yazısı Etrüskler tarafından İtalya' ya götürülmüştür.

Runik yazıları ile ilgili Türk araştırmacılar, Kazım Mirşan, İsmail Doğan, Turgay Kürüm Runik yazılarının Türk kökenli olduğunu ileri sürmektedirler.

Orta Asya'da Orhun ve Yenisey yazıtlarının bulunması üzerine O. Donner bunların İskandinav ülkerindeki Runik yazıtlara çok benzediğini ileri sürer ve yine A. Von Gabain bu yazının önce Talas bölgesinde ortaya çıktığını sonrada Orhun-Yenisey bölgesinde yazıldığını belirtmiştir $^{37}$. Antik kaynaklara ve arkeolojik bulgulara göre Etrüskler Anadolu (LidyaFrigya) üzerinden İtalya'ya göç eden bir kavimdir. Etrüskler sanat ürünlerinin, Türk sanat ürünlerine çok fazla benzerliği de göze çarpmaktadır. Etrüskler Turani bir kavimdir. Etrüskleri Türklere bağlayan en büyük güç ise Etrüsk yazısıdır. İsmail Doğan ve Adile Ayda, Etrüsk dilinde çok sayıda Türkçe kelime bulunduğunu ileri sürmektedirler.

İşte Atatürk'ün 1928'de kabul ettiği alfabe devrimi ile Latin alfabesinin kökeni budur. Dünyanın birçok ülkesinde kullanılan Latin alfabesi Etrüsk Runik alfabesinin bir tanesidir. Fenike alfabesi değildir ${ }^{38}$. Yazı Göktürk-Etrüsk kökenli yazıya dönüşmüştür. Bu da Latin alfabesini oluşturmuştur.

Özetle 1928'deki yazı alfabesi devrimiyle Türkçe yaklaşık 800 yıl sonra kendi öz benliği ile hiç uyuşmayan Arap harfleriyle yazılmaktan kurtularak kendi öz benliğine tamamen uygun Göktürk-Etrüsk yazısına dayanan Latin alfabesiyle neşredilmeye başlanmıştır.

\section{Yazı Devrimi}

Atatürk yazı devrimini durup dururken başlatmamıştır. Bunun bir alt yapısı vardır. 19. Yüzyıldan beri Osmanlı aydınları arasında ciddi bir şekilde alfabe tartışması vardır. Yazı devrimi Osmanlı'da Tanzimat'tan beri tartışılan ve toplumsal ihtiyaçtan doğan bir devrimdir. Osmanlı döneminde Latin alfabesi ile neşredilen ilk metin 1553 tarihlidir. Georgievits'in yazdığı bu metin daha sonra Fehmi Dinçer tarafından geliştirilmiştir ${ }^{39}$. Evliya Çelebi, Türkçe konuşan Anadolu'daki Rumlar Türkçe'yi Grek alfabesi ile yazmışlardır. Rumlar, Ermeniler Türkçe'yi kendi alfabeleri ile yazmışlardır.

Münif Paşa Latin harflerinin kolayca okunup yazılmasından bahseden, Arap harflerinin düzeltilmesini de ister. Mustafa Celaleddin Paşa 1869'da kızına Latin harfleri ile mektup yazmıştır. Tanzimat aydınlarından Ali Suavi, Ali Nusret, Ahmet Şakir Efendi Arap alfabesinin düzeltilmesini isterler. Bunlara karşın Hüseyin Cahit Yalçın, Dr. Abdullah Cevdet, Celal Nuri İleri, Kılıçzade Hakkı ise Latin alfabesine geçilmesini istemişlerdir. Atatürk bir bayan arkadaşına Latin alfabesi harfleriyle bir mektup yazmıştır. Tanzimat'tan Cumhuriyet'e geçen süre sonunda Osmanlı aydınları da Latin alfabesine geçilmesini savunmuşlardır. 19282010 aradan geçen 82 yılın sonrasında alınan bu kararın ne kadar isabetli olduğunu okuma yazma oranının yüzde 90ları aşmasından anlaşılmaktadır. Prof. Dr. Ahmet Mumcu da bunu kıvançla belirtmektedir ${ }^{40}$. Görüldüğ̈̈ gibi yazı devrimi bir gecelik anlık bir olay değildir.

Atatürk yazı devrimine çok büyük önem vermiştir. Onun medeni bilgiler kitabında, Türk milletinin dili Türkçe'dir. Türk dili dünyada en güzel, en zengin ve en kolay olabilecek bir dildir. Onun için her Türk dilini çok sever ve onu yükseltmek için çalışır. Türk dili, Türk milleti için kutsal bir hazinedir. Çünkü Türk milleti geçirdiği nihayetsiz felaketler içinde ahlakının ananelerinin, hatıralarının, menfaatlerinin kısacası bugün kendi milliyetini yapan

\footnotetext{
${ }^{37}$ Meydan, Cumhuriyet Tarihi Yalanlarl, s. 450-451.

${ }^{38}$ Meydan, Cumhuriyet Tarihi Yalanlarl, s. 452-453.

${ }^{39}$ Meydan, Cumhuriyet Tarihi Yalanlarl, s. 461; Milliyet Gazetesi, 29 Temmuz 2009.

${ }^{40}$ Ahmet Mumcu, Tarih Açısından Türk Devriminin Temelleri ve Gelişimi, İstanbul, 1996, s. 146.
} 
herşeyin dili sayesinde muhafaza olduğunu görüyor. Türk dili Türk milletinin zihnidir, kalbidir $^{41}$.

Fransız yazar Paul Gentizon, Atatürk'ün bu en büyük devrimi yazı devrimi konusunda; "Türkiye, Bulgaristan sınırından İran sınırına kadar bir okul açmıştı. Bu okulun baş öğretmeni de Atatürk” demektedir ${ }^{42}$. Atatürk yeni Türk harfleri çabuk öğrenilmelidir. Her vatandaş hamal, kadın, erkek çabucak öğrenmelidir. Bu yurtseverlik ve ulusseverliktir. Bir ülkede okur yazar oranının yüzde 10'larda seyretmesi büyük bir ayıptır.

\section{Sonuç}

Yazı ve dil devrimleri, Atatürk'ün en önemli ve en eşsiz devrimlerinin başında gelmektedir. Arap yazısı ve Arap dilini "kutsallaştırılmış" bir toplumda Arapça'nın egemenliğine son vererek Latin harflerine yönelmek unutturulmaya çalışılan Türkçe'yi arayıp bulmaya çalışmak çok büyük ve zahmetlidir ${ }^{43}$.

Türk dilinin ve biliminin Arap harfleri ile yayılmış veya basılmış önemli eserlerin de Türk harleri ile sadeleştirilerek tekrar yayınlanması eski kültür yaşamımızla olan ilişki kesilmeyecektir ${ }^{44}$. Bulgar Türkoloğu Manolog'da Türklerin bir gün mutlaka Latin alfabesini alacaklarını söylemektedir.

Halide Edip Adıvar, Latin harflerinin alınmasından yana tavır koymuştur. Erzurum Kongresi esnasında 1919 yılında M. Müfit Kansu'da Atatürk’ten yazının değiştirileceğini anlatmaktadir.

20 Mayıs 1928'de Dil Encümeni adlı bir okul oluşturulmuştur. Toplam 14 kişi Fransız, Alman, İngiliz, İtalyan, Macar alfabeleri incelenmiştir. Bu toplantılara katılan İnönü bu alfabeye "Türk Alfabesi” adını vermiştir ${ }^{45}$.

6 Ağustos 1928'de M.E.B. Mustafa Necati bir toplantı yapmış dil encümeni ile alfabeye son şekli verilmiştir ${ }^{46}$. Atatürk 29 Ağustos 1928 'de TBMM'de 1353 sayll kanunla Latin harfleri kabul edilmişti. Kanun 3 Aralık 1928'de yayınlanmış ve 1 Ocak 1929'dan sonra da Latin harfleri kullanılmaya başlanmıştır.

\section{Kaynakça}

Adıvar, H. E., (1962). Türkün ateşle imtihanı, İstanbul.

Akşin, S., (1997). Ana çizgileriyle Türkiye’nin yakın tarihi, Cilt: 2, İstanbul: İmaj Yayıncılık.

Atatürk'ün Bütün Eserleri, (1998). Cilt: 15, İstanbul: Kaynak Yayınları.

Aydemir, Ș. S., (2009). Tek adam, İstanbul: Remzi Kitabevi.

Aydoğan, M., (2018). Türkiye üzerine notlar, Ankara: Pozitif Yayıncılık.

Borak, S., (1998). Atatürk'ün İstanbul'daki çalışmaları, İstanbul: Kaynak Yayınları.

Cumhuriyet Dönemi Türkiye Ansiklopedisi, (1983). Cilt: 9-10, İstanbul: İletişim Yayınları.

Ergin, M. (1976). “Türklerde yazı ve alfabeler”, Türk Dünyası El Kitabı, Ankara.

Ergin, O., (1977). Türkiye maarif tarihi, Cilt: 2, Istanbul: Eser Neşriyat.

Goloğlu, M., (1971). Cumhuriyete doğru, Ankara: İş Bankası Kültür Yayınları.

İnan, A., (1969). Medeni bilgiler, Ankara: Örgün Yayınevi.

\footnotetext{
${ }^{41}$ Şükrü Akalın, Türk Dili Dergisi, Türk Dili Özel Sayısı, S.9 Ankara, 2004, s. 24.

${ }^{42}$ Paul Gentizon, Mustafa Kemal ve Uyanan Doğu, Ankara, 1994; Metin Aydoğan, Türkiye Üzerine Notlar, Ankara, 2018, s. 133.

${ }^{43}$ Meydan, Cumhuriyet Tarihi Yalanları, s. 484.

${ }^{44}$ Ahmet Mumcu, Tarih Açısından Türk Devriminin Temelleri ve Gelişimi, s. 146.

${ }^{45}$ Ülkütaşır, Atatürk ve Harf Devrimi, s. 59-60; Meydan, Cumhuriyet Tarihi Yalanları, s. 491.

${ }^{46}$ Zeynep Korkmaz, Atatürk ve Türk Dili Belgeler,Cilt: 1, Ankara, 1992, s. 5; Korkmaz, "Atatürk ve Türk Dili”, Türk Dil Dergisi, s. 27; Meydan, Cumhuriyet Tarihi Yalanlarl, s. 485.
} 
Karal, E. Z., (2001). Osmanlı tarihinde Türk dil sorunu, Ankara: Başkent Üniversitesi Yayınlar1.

Korkmaz, Z., (1992). Atatürk ve Türk dili belgeler, Ankara: TDK

Korkmaz, Z., (2006). “Atatürk ve Türk dili”, Türk Dil Dergisi, Say1: 655.

Meydan, S., (2020). Cumhuriyet tarihi yalanları, İstanbul: İnkılap Kitabevi.

Mumcu, A., (1996). Tarih açısından Türk devriminin temelleri ve gelişimi, İstanbul: İnkılap Kitabevi.

Şimşir, B. N., (1992), Türk yazı devrimi", Ankara: TDK ve TTK.

Tongul, N., (2004). "Türk harf ink1labı", Atatürk Yolu Dergisi, 9/3, 103-130.

Turan, Ş., (1998). Atatürk ve ulusal dil, Ankara: TDK.

Ülkütaş, M. Ş., (1973). Atatürk ve harf devrimi, Ankara: TDK. 